\title{
Morphological and Physiological Germination Aspects of Anadenanthera colubrina (Vell.) Brenan
}

\author{
Fernanda Carlota NERY ${ }^{1 *}$, Marcela Carlota NERY ${ }^{2}$, \\ Débora de Oliveira PRUDENTE 3 , Amauri Alves de ALVARENGA 3 , \\ Renato PAIVA ${ }^{3}$
}

\author{
${ }^{1}$ Universidade Federal de São João Del Rei (UFSJ), Departamento de Engenharia de Biossistemas, São João Del Rei - MG, \\ Brazil;fernandacarlota@ufsj.edu.br ( ${ }^{*}$ correspondingauthor) \\ ${ }^{2}$ Universidade dos Vales do Jequitinhonha e Mucuri (UFVJM), Diamantina - MG, Brazil; nery.marcela@gmail.com \\ ${ }^{3}$ Universidade Federal de Lavras (UFLA), Programa de Pós-graduação em Fisiologia Vegetal, Departamento de Biologia, Lavras - MG, \\ Brazil;deboraoprudente@outlook.com; amauriaa@dbi.ufla.br;renpaiva@dbi.ufla.br
}

\begin{abstract}
Anadenanthera colubrina is a species native to Brazil, from the Fabaceae family and has potential for use in the timber industry, in the reforestation of degraded areas, besides having medicinal properties. Its propagation is mainly by seeds, but basic subsidies regarding the requirements for optimal germination conditions are still lacking. Aiming to contribute to the expansion of its cultivation, rational use and conservation, the objective of this study was to investigate the morphology and anatomy of fruits and seeds, as well as the responses to factors as thermal regimes and substrates in seed germination. The 1000-seed weight and seeds per fruit were determined. To characterize the seed tissues, histochemical test with Sudan III and Lugol was used. The temperatures analyzed in the germination test were $15-25^{\circ} \mathrm{C} ; 25^{\circ} \mathrm{C} ; 20-30{ }^{\circ} \mathrm{C}$ and $30^{\circ} \mathrm{C}$. Different substrates for germination (paper rolls, paper sheet such as "germitest", commercial substrate and sand) were also analyzed in the presence of light at $30^{\circ} \mathrm{C}$. The average number of seeds per fruit is 10 and the 1000 -seed weight is $118 \mathrm{~g}$. Germination is fast and high over a wide temperature range; however, the temperature of $25^{\circ} \mathrm{C}$ contributes to a substantial increase in the percentage of abnormal seedlings and dead seeds, both in the absence and presence of light. A. colubrina seeds are indifferent to light and the highest vigor was verified at $30^{\circ} \mathrm{C}$. Sand and commercial substrates are efficient in initial seedling development.
\end{abstract}

Keywords: 'Angico-vermelho'; seedling generation; substrate; temperature

\section{Introduction}

In recent years, there has been a growing interest in the propagation of native forestry species, emphasizing the need for recovery of degraded areas and landscape restoration (Guerra and Jorge, 2017). In this context, studies involving seed technology, species ecophysiology and regeneration dynamics, associated with floristic and phytosociological surveys, are extremely important for the establishment of models that can be adopted and applied in management programs and to conduct forest regeneration processes (Candiani, 2006; Miranda et al., 2017). Thus, it is necessary to obtain basic information about the germination, cultivation and potentiality of native species, aiming at their use for the most diverse purposes. However, the available knowledge is still incipient when considering aspects such as seed analysis and management of most potential species, in order to provide data that can characterize their physical and physiological attributes (Ribeiro-Oliveira and Ranal, 2014).

Among the prominent native forest species from Brazil with potential for restoration of degraded areas is Anadenanthera colubrina (Vellozo) Brenan var. cebil (Griseb.) Altschul), belonging to the Fabaceae family (Pires et al., 2016). A. colubrina shows natural regeneration by seeds and has annual production, with barochory dispersal (Carvalho, 2003).

However, the morphological diversity within the Fabaceae family generates a series of taxonomic problems, increasing the search for information about the fruits, seeds and seedlings from this family species in order to complement those from vegetative organs and flowers 
594

(Oliveira, 1999). Therefore, the biometric characterization of fruits and seeds, as well as the study on seed requirements regarding the effects of temperature, light and ideal substrate for germination, provides important subsidies for the differentiation of pioneer and non-pioneer species in tropical forests and species from the same genus related to the characteristics of seedling dispersal and establishment, especially for species typical of secondary vegetation (Cruz et al., 2001; Fenner, 1993; Silva and Filho, 2006; Carvalho and Nakagawa, 2012).

Therefore, the objective of this study was to analyze the morphology and anatomy of fruit and seeds, the chemical composition of seeds, as well as their response to factors as imbibition, thermal regimes and substrates in germination.

\section{Materials and Methods}

\section{Plant material}

A. colubrina fruits were collected in approximately 50 matrix trees located at Universidade Federal de Lavras (UFLA), Lavras - Minas Gerais, Brazil, at the geographical coordinates $21^{\circ} 13^{\prime} 17^{\prime \prime} \mathrm{W}$ and $44^{\circ} 57^{\prime} 47^{\prime \prime} \mathrm{W}$. After collected, the fruits were processed and the seeds were removed and divided into two seed lots (A: Seeds that were naturally dispersed, i.e., collected on the ground; B: Seeds obtained from closed fruits). The seeds were packed in polyethylene packages and stored in a cold chamber $\left(8{ }^{\circ} \mathrm{C}\right.$ with $45 \%$ relative humidity), as recommended by Espinoza (2004).

\section{Morphological characterization of fruits and seeds}

Seeds (lots A and B) were mechanically ground by the oven dry method for 24 hours at $105 \pm 3{ }^{\circ} \mathrm{C}$ with values expressed in percentage on a wet basis (Brasil, 2009). Ripe fruits of brown color were randomly selected (approximately 100) from 50 matrix trees. A calliper with a precision of $0.05 \mathrm{~mm}$ was used to measure the length and width of fruits and seeds. Length was defined as the longitudinal distance between the apex and the base, whereas width corresponded to the measurement perpendicular to the median region of the fruits, expressed in centimeters $(\mathrm{cm})$. The number of seeds per fruit was obtained from a sample consisting of 100 fruits and the 1000-seed weight was determined using eight replicates of 100 seeds, weighed in an analytical balance with a precision of $0.001 \mathrm{~g}$, according to Brasil (2009); data average was expressed in grams $(\mathrm{g})$.

\section{Histochemical tests}

The seeds were submitted to manual cross sections and subsequent staining with safranin (Kraus and Arduin, 1997) and phloroglucinol (Foster, 1949). The cotyledons and embryonic axes were cross-sectioned to determine the type of reserve using the following reagents: Lugol, to qualify the presence of starch, and Sudan IV, for the identification of lipid bodies (Kraus and Arduin, 1997). The assembly of semi-permanent slides followed the techniques described by Johansen (1940). Visual observations were performed using an Olympus CBB microscope with photographic documentation using a digital camera $\left(\mathrm{Canon}^{\circ}\right)$, with resolution of 7.0 megapixels and $8 \times$ optical zoom.

\section{Ultrastructural characterization of embryonic axes}

For scanning electron microscopy, embryonic axes were collected and immersed in fixative solution (Karnovsky) $\mathrm{pH}$ 7.2 for a period of 24 hours, washed in sodium cacodylate buffer three times and post-fixed in $1 \%$ osmium tetroxide for 1 hour at room temperature. After this period, they were washed three times in distilled water and then dehydrated in increasing acetone gradients for 10 minutes each $(25 \%$, $50 \%, 75 \%, 90 \%$ and $100 \%$ three times). Subsequently, the material was taken to the critical point apparatus for complete drying, mounted on stubs and covered with gold. The specimens were observed in a LEO Evo 40 Scanning Electron Microscope, according to methodology described by Alves (2004). Ten replicates were used per treatment.

\section{Effect of temperature and luminosity on seed germination}

Seeds from lots A and B were submitted to different thermal regimes, in the absence or presence of constant light in an environment with $100 \%$ relative humidity. Germination tests were conducted at alternating and constant temperatures $\left(15-25^{\circ} \mathrm{C} ; 25^{\circ} \mathrm{C} ; 20-30{ }^{\circ} \mathrm{C}\right.$ and $30^{\circ} \mathrm{C}$ ), in a BOD germination chamber with photoperiod control. The substrate used was paper roll, moistened with distilled water 2.5 times the paper weight, placed in $250 \mathrm{~mL}$ beakers containing $2.0 \mathrm{~cm}$ water and covered with plastic bags to standardize humidity. In order to obtain the absence of light, the beakers were involved in black polyethylene packages. Germination was evaluated using a radicle protrusion of $\pm 2.0 \mathrm{~mm}$. Germinated seeds were kept in the paper roll in order to follow the initial growth and normal seedling count; evaluations were then performed after ten days. Abnormal seedlings were considered as having darkened apex root or epicotyl, absence of epicotyl or root, atrophied root or shoot at the end of the experiment. The percentage of dead seeds was also evaluated, having as criteria tissue softening and the presence of mycelium. Germination Speed Index (GSI) was determined together with germination and calculated according to the equation proposed by Maguire (1962). The treatments were distributed using a completely randomized design (CRD) and the analysis of variance was performed in a $2 \times 2 \times 4$ factorial design (seed lots $\times$ luminosity conditions $\times$ temperatures), with four replicates of 25 seeds for each treatment. Percentage data of normal and abnormal seedlings were transformed using $\sqrt{x}$, aiming at meeting the presumptions from the analysis of variance. For the other variables, there was no need for transformation.

\section{Effect of substrate on seed germination}

Seeds from lots A and B were submitted to different substrates for germination, paper roll, paper sheet (such as "germitest"), commercial substrate and sand, in the presence of light at a constant temperature of $30^{\circ} \mathrm{C}$. Paper sheet was moistened with an amount of distilled water equivalent to 2.5 times the dry paper weight; for the other substrates, acrylic boxes (gerbox) were used; water was added as necessary. A germination chamber was used, maintaining $100 \%$ relative humidity (Brasil, 2009). Germination was evaluated daily, using a radicle protrusion of $\pm 2.0 \mathrm{~mm}$ as a criterion. At the end of the experiment, after 10 days, the percentage of normal and abnormal seedlings, besides dead 
seeds, was evaluated. GSI was analyzed together with the germination test; the evaluations were performed daily from the radicle protrusion and calculated according to the equation proposed by Maguire (1962). The healthy test was performed, evaluating the presence of fungi in the seeds (qualitative data), using a magnifying glass and stereoscopic microscope due to their appearance.

\section{Morphological characterization of seedlings in different substrates}

The seedlings obtained in the previous test were evaluated after 10 days for shoot and root length, measured from 15 normal seedlings of each replication, with the aid of a graduated scale in millimeters $(\mathrm{mm})$. In order to determine the dry matter of the shoot and root system of normal seedlings, the lots were separated and placed in paper bags previously identified and taken to a convection oven regulated at $60^{\circ} \mathrm{C}$ for 72 hours. After this period, the seedlings were removed from the oven and weighed in an analytical balance with a precision of $0.001 \mathrm{~g}$; the results were expressed in grams (g). The treatments were distributed according to the CRD and the analysis of variance was performed in a $4 \times 2$ factorial design (substrates $\times$ seed lots), with four replicates of 25 seeds for each treatment.

\section{Statistical analyses}

The obtained data were subjected to analysis of variance using the Sisvar statistical software (Ferreira, 2014). The average among treatments was compared by Tukey's test at $5 \%$ probability.

\section{Results and Discussion}

\section{Morphological characterization of fruits and seeds}

The ripe $A$. colubrina fruit is dehiscent and brown colored (Fig. 1A). The average number of seeds per fruit is 10. The average fruit length is $15 \mathrm{~cm}$ and the 1000 -seed weight is $118 \mathrm{~g}$. The seeds show length average of $1.50 \mathrm{~cm}$, width or diameter average of $1.62 \mathrm{~cm}$ and thickness average of $0.83 \mathrm{~mm}$.

The seed is morphologically flat and shiny, with a narrow wing (Fig. 1B). The embryo, which is light yellow, consists of two flat cotyledons, foliaceous, with an approximately circular contour and a basal cleft that ends at their insertion point in the hypocotyl-radicle axis (Fig. 1C), which is short and straight, exposed by the basal incision of cotyledons.
The results obtained in this study are in agreement with those reported for the same species by Espinoza (2004), with fruit length between $18 \mathrm{~cm}$ and $20 \mathrm{~cm}$ in lots collected in successive years, while the average width was $2.1 \mathrm{~cm}$ in samples from Cochabamba, Bolivia, at altitudes between $1,990 \mathrm{~m}$ and 2,100 $\mathrm{m}$. The same author reported that seed diameter varied between $1.66 \mathrm{~cm}$ and $1.72 \mathrm{~cm}$.

The observation of the embryonic axis to the scanning electron microscope showed that the plumule is differentiated, with delimited leaflets (Fig. 1D). The plumule is folded over the long and arcuate epicotyl, at an angle of about $180^{\circ}$, as described by Oliveira (1999). Numerous multifoliolate leaflets are differentiated in the plumule, where rachis and leaflets are visible (Fig. 1D). The protoderm is glabrous in the hypocotyl-radicle axis, with numerous trichomes in differentiation on epicotyl, pluricellular glandular type (Fig. 1E). Cotyledons are thin and rich in lipids (Fig. 1F), and are not detected the presence of starch. The embryonic axis of $A$. colubrina seeds is differentiated; the cells are rich in lipids and with little amount of starch grains (Figs. 1G, 1H and 1I).

The obtained results corroborate those by Nascimento et al. (2007), who observed the presence of a non-specific material reacting with Schiffs reagent with globular characteristics in the cell cytoplasms of cotyledons from germinated A. colubrina seeds with $1.0 \mathrm{~mm}$ radicle length. According to the authors, it is probably glycoproteins and not starch, since the lugol reaction was not positive for this polysaccharide. This result is in accordance with those obtained in this study for A. colubrina, since the presence of starch in cotyledons was not detected.

Oliveira (1999) described the embryos of two species from the Mimosoideae subfamily, especially the embryonic axis of $A$. macrocarpa (Benth.) as having differentiated plumules, when there are distinguishable leaf primordia, leaflet, stipule and/or petiole differentiation may occur. The same author observed the presence of numerous differentiated non-glandular and glandular trichomes for Inga urugüensis, also taniferous, with idioblasts both in the protoderm and in the fundamental meristem, especially in the cortical region.

\section{Effect of temperature and luminosity on seed germination}

There was no significant effect for the triple interaction between seed lots, luminosity conditions and thermal regimes for all analyzed variables (Table 1). The significant double interaction between luminosity and temperature

Table 1. Mean values of germination percentage (G\%), dead seeds (DS\%) and Germination Speed Index (GSI) in lots A and B of $A$. colubrina seeds, under different lighting conditions and thermal regimes

\begin{tabular}{|c|c|c|c|}
\hline Treatments & $\mathrm{G}(\%)$ & DS (\%) & GSI \\
\hline \multicolumn{4}{|l|}{ Lots } \\
\hline A & $93 \mathrm{a}$ & $6 \mathrm{~b}$ & $19.20 \mathrm{a}$ \\
\hline B & $88 \mathrm{~b}$ & $10 \mathrm{a}$ & $16.16 \mathrm{~b}$ \\
\hline \multicolumn{4}{|l|}{ Luminosity } \\
\hline Presence & $90 a$ & $9 a$ & $17.45 \mathrm{a}$ \\
\hline Absence & $91 \mathrm{a}$ & $7 a$ & $17.91 \mathrm{a}$ \\
\hline \multicolumn{4}{|c|}{ Temperatures $\left({ }^{\circ} \mathrm{C}\right)$} \\
\hline 25 & $81 \mathrm{~b}$ & $17 a$ & $17.16 \mathrm{~b}$ \\
\hline 30 & $96 a$ & $6 b$ & $20.59 a$ \\
\hline $15-25$ & $91 \mathrm{a}$ & $6 \mathrm{~b}$ & $17.84 \mathrm{~b}$ \\
\hline $20-30$ & $93 a$ & $3 b$ & $15.12 \mathrm{c}$ \\
\hline
\end{tabular}

Means followed by the same lowercase letter in each column are not significantly different using Tukey's test at $p<0.05$. 
596

conditions was verified only for the percentages of normal and abnormal seedlings (Table 2).

With respect to germination, the constant temperature of $30^{\circ} \mathrm{C}$ and alternating regimes of $15-25^{\circ} \mathrm{C}$ and $20-30^{\circ} \mathrm{C}$ provided a higher germination percentage in the seeds from

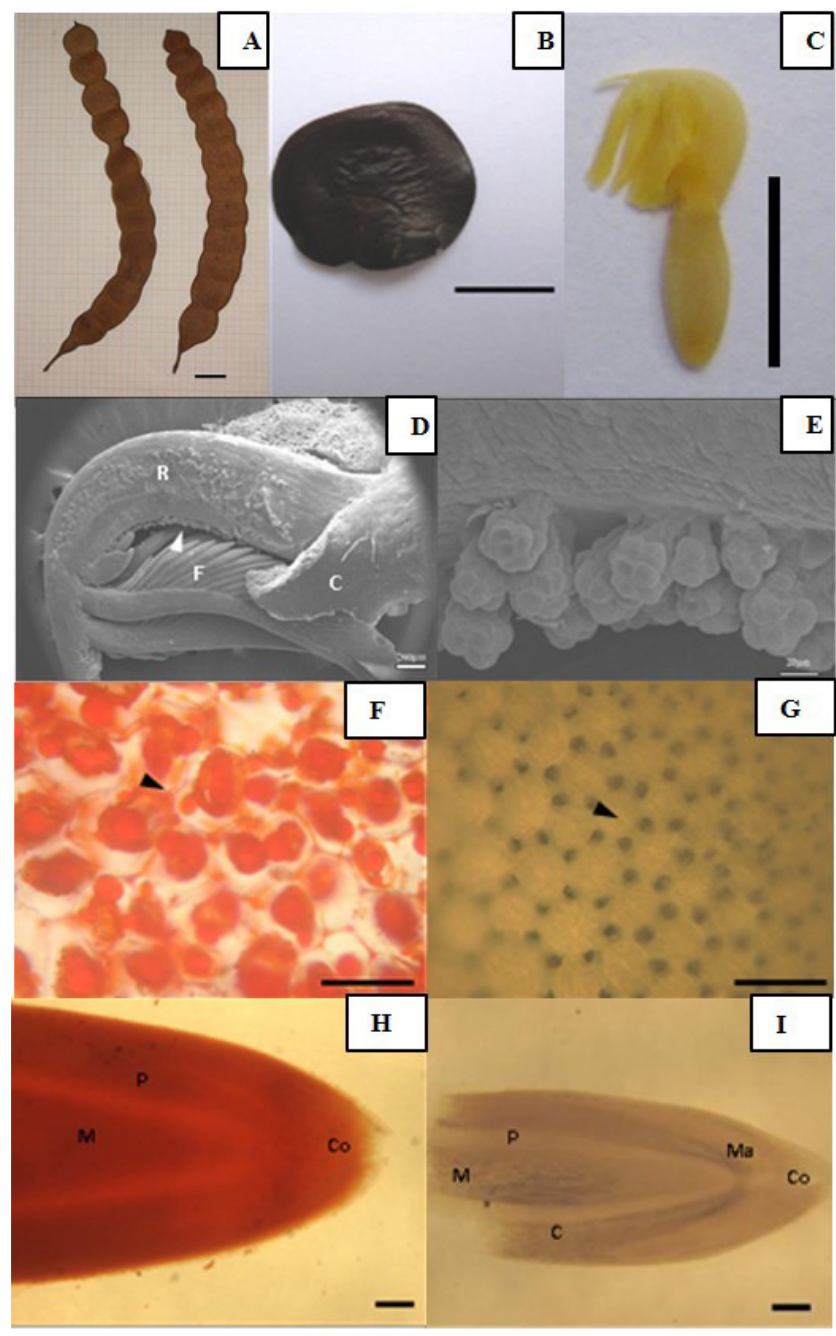

Fig. 1. Appearance of fruits (A); fruits with whole seed husk (B); and embryo axis (C); Embryonic axis scanning of $A$. colubrina seeds (D); plumule with trichomes in the lower part of the pluto-hypocotyl axis (E); (arrow: differentiating trichomes, F: leaflets; R: rachis; C: cotyledons attached to the axis). Photomicrography of cotyledonary ( $F$ and $G$ ) and longitudinal sections of the embryonic axis ( $\mathrm{H}$ and $\mathrm{I}$ ) of $A$. colubrina seeds stained with Sudan III (F and G) and Lugol (H and I) (arrows: lipid and starch grains, M: fundamental meristem, P: procambium, Co: root cap, C: cortex, Ma: apical meristem). $\operatorname{Bar}(\mathrm{A})=2.0 \mathrm{~cm}, \operatorname{bar}(\mathrm{B})=1.0 \mathrm{~cm}, \operatorname{bar}(\mathrm{C})=0.5$ $\mathrm{cm}$, bars $(\mathrm{F}$ and $\mathrm{G})=0.5 \mu \mathrm{m}$ and bars $(\mathrm{H}$ and $\mathrm{I})=20 \mu \mathrm{m}$ lot A, but there was no effect on luminosity conditions. It is observed that the temperature of $25^{\circ} \mathrm{C}$ yielded a higher percentage of dead seeds from lot B (Table 1). Regarding GSI, a higher vigor was verified in seeds from lot $\mathrm{A}$ at $30^{\circ} \mathrm{C}$, regardless of luminosity conditions (Table 1). The highest percentage of normal seedlings was verified in seeds from lot $\mathrm{A}$, and abnormal seedlings in seeds from lot $\mathrm{B}$ (Table 2).

Through the data obtained for double interaction between luminosity and temperature conditions, it was verified that the percentage of normal seedlings was superior at a constant temperature of $30^{\circ} \mathrm{C}$ in the presence of light and alternating temperature of $20-30{ }^{\circ} \mathrm{C}$ in the absence of light, without significant differences for the other treatments. For the percentage of abnormal seedlings, the lowest value was observed at the alternating temperature of 20-30 ${ }^{\circ} \mathrm{C}$; the other treatments did not differ among themselves (Table 3). Compared with every luminosity condition, when seeds were submitted to the presence or absence of light, a lower percentage of normal seedlings occurred at a constant temperature of $25^{\circ} \mathrm{C}$ (Table 3 ). Regarding the percentage of abnormal seedlings, both in the presence and absence of light, the highest percentage was observed at $25^{\circ} \mathrm{C}$.

According to Ramos and Varela (2003), the ideal germination temperature generally varies within the temperature range found at the site and in the ideal period for the emergence and establishment of seedlings. In studies performed with $A$. colubrina, it was observed that the percentage of seedling formation did not show statistical differences between the analyzed temperatures (20,25, and $30{ }^{\circ} \mathrm{C}$ constant); however, they concluded through the analyzed variables that the temperature of $20^{\circ} \mathrm{C}$ is the more suitable for seed germination and seedling development (Paim et al., 2016). The obtained information proves that A. colubrina seeds can be positively or negatively influenced by light or behave indifferently to it, concluding that they do not have photosensitivity.

\section{Effect of substrate on seed germination}

On paper roll, a higher germination percentage (radicle protrusion) and normal seedlings were observed in the seeds from lot B. For the other substrates, there were no significant differences among seed lots (Table 4). Regarding GSI, a higher value was verified for the seeds from lot A using sand and paper roll substrates, and there were no differences in the amount the other substrates for both lots. A higher vigor was observed in lot $\mathrm{A}$ when sand was used and within lot $\mathrm{B}$, also on sand and commercial substrate (Table 4). Abnormal seedlings and dead seeds were observed on paper roll (Table 5).

The characteristics of shoot length, root system length and dry matter of the root system were influenced by the double interaction between substrates and seed lots (Table 6). Seeds from lot A, germinated on paper roll and on sand, showed larger shoot length, unlike seedlings of germinated

Table 2. Percentage of normal seedlings (NS\%) and abnormal seedlings (AS\%) in lots A and B of $A$. colubrina seeds

\begin{tabular}{ccc}
\hline Lots & NS (\%) & AS (\%) \\
\hline A & $85 \mathrm{a}$ & $10 \mathrm{~b}$ \\
$\mathrm{~B}$ & $69 \mathrm{~b}$ & $17 \mathrm{a}$ \\
$\mathrm{CV}(\%)$ & 11.95 & 6.38 \\
\hline
\end{tabular}

Means followed by the same lowercase letter in each column are not significantly different using Tukey's test at $p<0.05$. 
Table 3. Percentage of normal and abnormal seedlings for interaction between different light conditions and thermal regimes in lots $\mathrm{A}$ and $\mathrm{B}$ of $A$. colubrina seeds

\begin{tabular}{|c|c|c|}
\hline \multirow{2}{*}{ Temperatures $\left({ }^{\circ} \mathrm{C}\right)$} & \multicolumn{2}{|c|}{ Luminosity } \\
\hline & Presence & Absence \\
\hline & \multicolumn{2}{|c|}{ Normal seedlings (\%) } \\
\hline 25 & $62 \mathrm{aB}$ & $55 \mathrm{aC}$ \\
\hline 30 & $85 \mathrm{aA}$ & $75 \mathrm{bB}$ \\
\hline $15-25$ & $86 \mathrm{aA}$ & $87 \mathrm{aA}$ \\
\hline \multirow[t]{2}{*}{$20-30$} & $77 \mathrm{bA}$ & $88 \mathrm{aA}$ \\
\hline & \multicolumn{2}{|c|}{ Abnormal seedlings (\%) } \\
\hline 25 & $20 \mathrm{aA}$ & $28 \mathrm{aA}$ \\
\hline 30 & $7 \mathrm{aBC}$ & $8 \mathrm{aB}$ \\
\hline $15-25$ & $10 \mathrm{aC}$ & $5 \mathrm{aB}$ \\
\hline $20-30$ & $18 \mathrm{aAB}$ & $9 \mathrm{bB}$ \\
\hline
\end{tabular}

Means followed by the same lowercase letter in each line and the same uppercase letter in each column are not significantly different using Tukey's test at $p<0.05$.

Table 4. Percentage of germination (G\%), germination speed index (GSI) and normal seedlings (NS\%), for different substrates in lots A and B of $A$. colubrina seeds

\begin{tabular}{|c|c|c|}
\hline \multirow{2}{*}{ Substrates } & \multicolumn{2}{|c|}{ Lots } \\
\hline & $\bar{A}$ & B \\
\hline & \multicolumn{2}{|c|}{ Germination (\%) } \\
\hline Paper roll & $73 \mathrm{bB}$ & $94 \mathrm{aA}$ \\
\hline Paper sheet & $95 \mathrm{aA}$ & $100 \mathrm{aA}$ \\
\hline Commercial substrate & 96 aA & $94 \mathrm{aA}$ \\
\hline Sand & $97 \mathrm{aA}$ & $98 \mathrm{aA}$ \\
\hline \multicolumn{3}{|l|}{$\mathrm{CV}(\%)=5.88$} \\
\hline \multicolumn{3}{|c|}{ GSI } \\
\hline Paper roll & $21.21 \mathrm{aAB}$ & $13.46 \mathrm{bB}$ \\
\hline Paper sheet & $14.42 \mathrm{aC}$ & $14.00 \mathrm{aB}$ \\
\hline Commercial substrate & $17.47 \mathrm{aBC}$ & $19.58 \mathrm{aA}$ \\
\hline Sand & $22.79 \mathrm{aA}$ & $19.46 \mathrm{bA}$ \\
\hline \multicolumn{3}{|l|}{$\mathrm{CV}(\%)=11.51$} \\
\hline \multicolumn{3}{|c|}{ Normal seedlings (\%) } \\
\hline Paper roll & $67 \mathrm{bB}$ & $88 \mathrm{aA}$ \\
\hline Paper sheet & $83 \mathrm{aA}$ & $88 \mathrm{aA}$ \\
\hline Commercial substrate & $94 \mathrm{aA}$ & 91 aA \\
\hline Sand & 93 aA & 96 aA \\
\hline $\mathrm{CV}(\%)=8.35$ & & \\
\hline
\end{tabular}

Means followed by the same lowercase letter in each line and the same uppercase letter in each column are not significantly different using Tukey's test at $\mathrm{p}<0.05$.

Table 5. Percentage of abnormal seedlings (AS\%) and dead seeds (DS\%) for different substrates in lots A and B of A. colubrina seeds

\begin{tabular}{ccc}
\hline Substrates & AS (\%) & DS $(\%)$ \\
\hline Paper roll & $7 \mathrm{a}$ & $15 \mathrm{a}$ \\
Paper sheet & $0 \mathrm{~b}$ & $2 \mathrm{~b}$ \\
Commercial substrate & $3 \mathrm{ab}$ & $4 \mathrm{~b}$ \\
Sand & $2 \mathrm{ab}$ & $2 \mathrm{~b}$ \\
\hline
\end{tabular}

Means followed by the same lowercase letter in each column are not significantly different using Tukey's test at $p<0.05$.

seeds from other substrates. Evaluating the same variable within lot B, a better behavior was observed for seedlings in commercial substrate, probably due to the physical constitution of this substrate, which allows better oxygenation conditions to the seedlings. When the seed lots were compared within each substrate, a larger paper roll length was verified for lot $A$ and in commercial substrate for lot B, not differing for the other substrates (Table 6).
Regarding root system growth, length in lot A was greater on paper roll and commercial substrate and, within lot $\mathrm{B}$, a higher value was observed in commercial substrate. In the comparison of seed lots within each substrate, it was verified that seeds from lot A showed a longer root length than seeds from lot B in paper roll, and there were no significant differences for the other treatments (Table 6). Regarding dry matter of the root system, there was no 
Table 6. Root length (RL), shoot length (SL) and root dry matter (mg) (RDM) for different substrates in lots A and B of A. colubrina seeds

\begin{tabular}{|c|c|c|c|c|c|c|}
\hline \multirow{3}{*}{ Substrates } & \multicolumn{2}{|c|}{ RL } & \multicolumn{2}{|c|}{ SL } & \multicolumn{2}{|c|}{ RDM } \\
\hline & \multicolumn{6}{|c|}{ Lots } \\
\hline & $\mathrm{A}$ & B & $\mathrm{A}$ & B & $\mathrm{A}$ & B \\
\hline Paper roll & $13.18 \mathrm{aA}$ & $1.27 \mathrm{abB}$ & $12.33 \mathrm{aA}$ & $7.63 \mathrm{bB}$ & $18.2 \mathrm{aA}$ & $7.7 \mathrm{bB}$ \\
\hline Paper sheet & $9.92 \mathrm{bA}$ & $9.36 \mathrm{bA}$ & $7.20 \mathrm{bA}$ & $6.35 \mathrm{bA}$ & $15.6 \mathrm{aA}$ & $15.8 \mathrm{aA}$ \\
\hline Commercial substrate & $11.14 \mathrm{bB}$ & $12.69 \mathrm{aA}$ & $10.73 \mathrm{aA}$ & $11.28 \mathrm{aA}$ & $12.9 \mathrm{aB}$ & $17.4 \mathrm{aA}$ \\
\hline Sand & $9.56 \mathrm{bA}$ & $10.71 \mathrm{bA}$ & $6.48 \mathrm{bA}$ & $6.15 \mathrm{bA}$ & $14.8 \mathrm{aA}$ & $16.1 \mathrm{aA}$ \\
\hline
\end{tabular}

Means followed by the same lowercase letter in each line and the same uppercase letter in each column are not significantly different using Tukey's test at $p<0.05$.

Table 7. Shoot dry matter (SDM), root dry matter (RDM) and ratio (SDM/RDM) of normal seedlings for different substrates in lots $\mathrm{A}$ and $\mathrm{B}$ of $A$. colubrina seeds

\begin{tabular}{ccc}
\hline Substrates & SDM & SDM/RDM \\
\hline Paper roll & $74.7 \mathrm{bc}$ & $0.1842 \mathrm{~b}$ \\
Paper sheet & $72.2 \mathrm{c}$ & $0.2852 \mathrm{a}$ \\
Commercial substrate & $104.9 \mathrm{a}$ & $0.1817 \mathrm{~b}$ \\
Sand & $101.3 \mathrm{ab}$ & $0.1758 \mathrm{~b}$ \\
$\mathrm{CV}(\%)$ & 91.70 & 92.52 \\
\hline
\end{tabular}

Means followed by the same lowercase letter in each column are not significantly different using Tukey's test at $p<0.05$.

significant difference among different substrates for lot $\mathrm{A}$ and, for lot $\mathrm{B}$, the lowest value was observed in paper roll; the other treatments did not differ among themselves. Comparing the seed lots within each substrate, there was a higher dry matter of the root system for seeds from lot $\mathrm{A}$ on paper roll and for seeds from lot B in commercial substrate, with no differences among seed lots within the substrates on paper and sand (Table 6).

Regarding shoot dry matter and its relation with the root system, the double interaction between seed lots and different substrates was not significant. A higher shoot dry matter accumulation was obtained in seedlings germinated in commercial substrate, while lower values were observed in substrate on paper. The relationship between root and shoot dry matter was higher in substrate on paper than in the other substrates (Table 7). This test can be used to evaluate seedling growth and to determine, with greater precision, the transfer of dry matter from the reserve tissues to the embryonic axis in the germination phase, originating seedlings with higher weight due to the higher dry matter accumulation (Nakagawa, 1999).

Kissmann et al. (2008) conducted studies with the objective of evaluating temperature and ideal substrates for the germination of Adenanthera pavonina L. seeds. These authors observed higher germination values in substrates on paper and paper roll averaging $86 \%$, and no significant differences were observed in the dry weight of seedlings, averaging $1.08 \mathrm{~g}$, submitted to different temperatures and substrates. According to Figliolia et al. (1993), the use of vermiculite proved to be inadequate for $M$. caesalpiniifolia seeds. The authors also describe that seeds from this species are indifferent to light during germination, and the latter result is similar to that obtained in this study for $A$. colubrina seeds.

Amaro et al. (2006) studied the influence of light and temperature on the germination of janaguba (Himatanthus drasticus (Mart.) Plumel.) seeds and verified that these seeds show neutral photoblastism; temperatures of $20{ }^{\circ} \mathrm{C}$ and $25^{\circ} \mathrm{C}$, combined with constant dark and light/dark, and temperatures of $30{ }^{\circ} \mathrm{C}$ and $20-35{ }^{\circ} \mathrm{C}$, combined with light/dark, are the most favorable conditions for germination. The combination of temperatures of $25^{\circ} \mathrm{C}$ and $30^{\circ} \mathrm{C}$ and the absence of light increase the speed and reduce the average germination time of this species.

Melo et al. (2005) evaluated the effect of different substrates on the germination of Anadenanthera colubrina (Vell.) Brenan seeds under laboratory conditions and observed that the highest seed germination percentage occurred in the substrates between sand and vermiculite at $30^{\circ} \mathrm{C}$ and 12-hour photoperiod. They also found that the substrate between paper sheet showed the worst performance, with the lowest numbers of germinated seeds and the highest number of abnormal seedlings. These authors reported that, although all the substrates used have the partial restriction of light incidence on the seeds as a common characteristic, the difference can be explained by the low thermal conductivity of paper sheet, which caused the germination percentage of this treatment to be significantly lower, when compared to the others.

\section{Conclusions}

The seminal anatomy of $A$. colubrina is typical of the Mimosoideae subfamily. The number of seeds per fruit is 10 on average and the 1000-seed weight ranges 118 g. $A$. colubrina seeds are indifferent to light and the highest vigor was verified at $30^{\circ} \mathrm{C}$. Sand and commercial substrates are efficient in initial seedling development.

\section{Acknowledgements}

This study was supported by Conselho Nacional de Desenvolvimento Científico e Tecnológico (CNPq; Brasília, DF-Brazil), Fundação de Amparo à Pesquisa de Minas Gerais (FAPEMIG; Belo Horizonte, MG-Brazil) and Coordenação de Aperfeiçoamento de Pessoal de Nível Superior (CAPES; Brasília, DF-Brazil). 


\section{References}

Alves E (2004). Curso introdutório de microscopia eletrônica de varredura [Introductory course of elementary microscopy of varredura]. Editora UFLA, Lavras.

Amaro MS, Filho SM, Guimarães, RM, Teófilo EM (2006). Influência da temperatura e regime de luz na germinação de sementes de janaguba (Himatanthus drasticus (Mart.) Plumel.) [Influence of temperature and light regime on germination of Janaguba (Himatanthus drasticus (Mart.) Plumel.)]. Ciênciae Agrotecnologia 30(3):450-457.

Añez LMM, Coelho MFB, Albuquerque MCF, Dombroski JLD (2005). Morphological characterization of fruits, seeds and seedling development of Jatropha elliptica Müll. Arg. (Euphorbiaceae). Revista BrasileiradeBotânica 28(3):563-568.

Araújo NetoJC, Aguiar IB, Ferreira VM (2003). Efeito da temperatura e da luz na germinação de sementes de Acacia polyphylla DC [Effect of temperature and light on seed germination of Acacia polyphylla DC]. Revista Brasileira Botânica 26(2):249-256.

Araújo Neto JC, Aguiar IB, Ferreira VM, Paula RC (2002). Morphological characterization of fruits and seeds and post-seminal development of monjoleiro (Acacia polyphylla DC.). Revista Brasileira de Sementes 24(1):203-211.

Barbosa DCA (2003). Strategies of germination and growth of woody species of caatinga with fast germination. In: Leal IR, Tabarelli M, Silva JMC (Eds). Ecologia e conservação da caatinga. Recife: Universidade Federal de Pernambuco pp 625-656.

Baskin JM, Baskin CC (1992). Role of temperature and light in the germination ecology of buried seeds of weedy species of disturbed forests. I. Labelia inflata. Canadian Journal of Botany 70(3):589-592.

Bewley JD, Black M (1994). Seeds: physiology of development and germination. New York: Plenum.

Borges IF, Neto JDG, Bilia DAC, Ribeiro RCLF, Barbedo CJ (2005). Maturation of seeds of Caesalpinia echinata Lam. (Brazilwood), an endangered leguminous tree from the brazilian atlantic forest. Brazilian Archives of Biology and Technology 48(6):851-861.

Brasil (2009). Ministério da Agricultura, do Abastecimento e da Reforma Agrária. Regras para análise de sementes [Rules for seed analysis]. Brasilia: NAD/DNDV/CLAV.

CarvalhoNM, NakagawaJ (2012). Sementes: ciência, tecnologia e produção [Seeds: science, technology and production]. 5 ed. FUNEP.

Carvalho PER (2003). Espécies Arbóreas Brasileiras [Brazilian Arboreal Species].v.1.EditoraEMBRAPA. Colombo, Brasil.

Chaves LLB, Carneiro JGA, Barroso DG (2006). Growth of Anadenanthera macrocarpa (Benth) Brenan (angico-red) seedlings on fertilized substrate and inoculated with rhizobia. Revista Árvore 30(6):911-919.

CruzED, Martins FO, CarvalhoJEU (2001). Fruit and seed biometry and germination of jatobá-curuba (Hymenaea intermedia Ducke, Leguminosae - Caesalpinioideae). Revista Brasileira de Botânica 24(2):161-165.

Damião-Filho CF (1993). Morfologia vegetal [Plant morphology]. Jaboticabal: FUNEP/UNESP.
Espinoza ER (2004). Desiccation and storage of Anadenanthera colubrina seeds. In: Storage biology of tropical tree seeds. BASFOR: Centro de Semillas Forestales.

Fenner M (1993).Seed ecology.London: Chapman \& Hall.

Ferraz GA, Takaki M (2006). Effects of light, temperature and water stress on seed germination Caesalpinia peltophoroides Benth. (Caesalpinoideae). Bragantia 65(1):37-42.

Ferreira DF (2014). SISVAR - Sistema de análise de variância para dados balanceados: versão 4.6. Lavras: UFLA.

Figliolia MB, Oliveira EC, Piña-Rodrigues FCM (1993). Análise de Sementes. In: Aguiar IB, Piña-Rodrigues F, Figliola MB (Org). Sementes Florestais Tropicais [Tropical Forest Seeds]. Brasilia: ABRATES.

Foster AS (1949). Practical Plant Anatomy. Princeton, D. Van Nostrand. Co.Inc.

Guerra AJT,Jorge MDCO (2017).Processos erosivos e recuperação deáreas degradadas [Erosive processes and recovery of degraded areas]. São Paulo: Oficina de Textos.

Gunn CR (1984). Fruits and seeds of genera in the subfamily Mimosoideae (Fabaceae). Technical Bulletin United States Department of Agriculture, Washington n. 1681.

Johansen DA (1940). Plant microtechnique.Mc Graw Hill,New York.

Kissmann C, Scalon SPQ, Filho HS, Ribeiro N (2008). Treatments to break dormancy, temperatures and substrates in the germination of Adenantherapavonina L. Ciênciae Agrotecnologia 32(2):668-674.

Kraus JE, Arduin M (1997). Manual básico de métodos em morfologia vegetal [Basic manual of methods in plant morphology]. Editora da Universidade Rural, Rio de Janeiro.

Labouriau LG, Marques IF, Labouriau MLS, Handro W (1963). Nota sobre a germinação de sementes de plantas de cerrados em condições naturais. Revista Brasileira de Biologia 23(3):227-237.

Lorenzi H (2000). Árvores brasileiras: manual de identificação, e cultivo de plantas arbóreas nativas do Brasil [Brazilian trees: identification manual, and cultivation of native tree plants in Brazil]. 3 ed. Nova Odessa: Instituto Plantarum.

Maciel AS, Borges EEL, Borges RCG (1992). Determination of the presence of phenols in seeds of forest species and its relation with inhibitors of germination. Revista Brasileira deSementes 14(1):1-4.

Maguire JD (1962). Speed of germination- aid in selection and evaluation for seedlingemergence and vigor. CropScience 2(2):176-177.

Melo RR, Ferreira AG, Junior FR (2005). Efeito de diferentes substratos na germinação de sementes de angico (Anadenanthera colubrina (Vell.) Brenan) em condições de laboratório. Revista Científica Eletrônica de Engenharia Florestal 5:1678-3867.

Miranda RMD, Dias DCFDS, Picoli EAD, Silva PPD, Nascimento WM (2017). Physiological quality, anatomy and histochemistry during the development of carrot seeds (Daucus carota L.). Ciência e Agrotecnologia 41(2):169-180.

Nakagawa J (1999). Testes de vigor baseados no desempenho das plântulas. In: Krzyzanowski FC, Vieira RD, França Neto JB (Ed). Vigor de sementes: conceitos e testes [Seed vigor: concepts and tests]. Londrina: ABRATES. 
600

Nascimento PL, Mesquita JM, Brito ES, Gallão MI (2007). Mobilization of Anandenathera colubrina (Vell.) Seed reserves after germination. Revista Brasileira de Biociências 5(2):966-968.

NassifSML, Vieira IG, Fernades GD (2006). (LARGEA/). Fatores externos (ambientais) que influenciam na germinação de sementes [External factors (environmental) that influence seed germination]. Piracicaba: IPEF/LCF/ESALQ/USP, InformativoSementes IPEF.

Novembre ADLC, Faria TC, Pinto DHV, Chamma HMCP (2007). Test of seed germination of sansão-do-campo (Mimosa caesalpiniaefolia Benth. - Fabaceae-Mimosoideae). Revista Brasileira de Sementes 29(3):47-51.

Oliveira DMT (1999). Morpho-anatomy of the embryo of native tree legumes. Revista Brasileira de Botânica 22(3):413-427.

Oliveira EC (1993). Morfologia de plântulas florestais. In: Aguiar IB, PiñaRodrigues FCM, Figliolia MB (Eds). Sementes Florestais Tropicais [Tropical Forest Seeds]. Brasilia: ABRATES pp 175-214.

Paim LP, Avrella ED, Fior CS (2016). Seed germination of Anadenanthera colubrina (Vellozo) Brenan at different temperatures. Revista da Jornada da Pós-Graduação e Pesquisa-Congrega Urcamp 91(1):573-582.

Passos MA, Tavares KMP, Alves AR (2007). Seed germination of sabiá (Mimosa caesalpiniifolia Benth.). Revista Brasileira de Ciências Agrárias 2(1):51-56.
Passos MAA, Silva FJBC, Silva ECA, Pessoa MML, Santos RC (2008). Light, substrate and temperature on germination of red cedar seeds. Pesquisa Agropecúaria Brasileira 43(2):281-284.

Perez SCJGA, Fanti SC, Casali CA (2001). Influence of light on the germination of canafistula seeds submitted to water stress. Bragantia 60(3):155-166.

Ramos MBP, Varela VP(2003). Effect of temperature and substrate on seed germination of visgueiro do igapó (Parkia discolor Benth) Leguminosae, Mimosoideae. Revistade Ciências Agrárias 39(1):123-133.

Ribeiro-Oliveira JP, Ranal M A (2014). Sementes florestais brasileiras: início precário, presente inebriante e o futuro, promissor? [Brazilian forest seeds: precarious onset, intoxicating present, and the future promising?]. Ciência Florestal 24(3):771-784.

Silva MAP, Filho SM (2006). Fruit, seed and seedling morphology of piqui (Caryocar coriaceum Wittm.). Revista Ciência Agronômica 37(3):320325.

Strapasson M, Santos AF, Medeiros ACS (2002). Fungi associated with angico seeds (Piptadenia paniculata). Boletim de Pesquisa Florestal 45(1):137-141.

Varela VP, Costa SS, Ramos MBP (2005). Influence of temperature and substrate on seed germination of itaubarana (Acosmium nitens (Vog) Yakovlev)-Leguminosae, Caesalpinoideae. ActaAmazonica35(1):35-39. 